Supporting Information

\title{
Polyallene-block-Polythiophene-block-Polyallene Copolymers: One-pot Synthesis, Helical Assembly and Multiresponsiveness
}

Zhi-Peng Yu, Cui-Hong Ma, Qian Wang, Na Liu,* Jun Yin, and Zong-Quan Wu*

Department of Polymer Science and Engineering, School of Chemistry and Chemical Engineering, Hefei University of Technology and Anhui Key Laboratory of Advanced Functional Materials and Devices, Anhui Province, Hefei 230009, China 
Figure S1: SEC traces of poly-140, poly(140-b-280), and poly(140-b-280-b-140) using UV detector $\cdots \cdots$ S3

Figure S2: SEC chromatograms of poly $\left(\mathbf{1}_{15}-b-\mathbf{2}_{\mathrm{n}}\right) \mathrm{s}$ prepared using poly-1 $\mathbf{1}_{15}$ as initiator $\cdots \cdots \cdots \cdots \cdots \cdot \mathrm{S} 3$

Figure S3: SEC chromatograms of PHA, PHA- $b$-P3HT and PHA- $b$-P3HT- $b-$ PHA $\cdots \cdots \cdots \cdots \cdots \cdots \cdots \cdot \ldots$

Figure S4: FT-IR spectra of PHA, P3HT, PHA- $b$-P3HT and PHA- $b$-P3HT- $b$-PHA $\cdots \cdots \cdots \ldots \ldots \ldots . . . . .64$

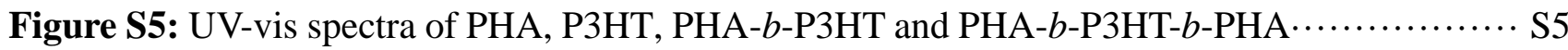

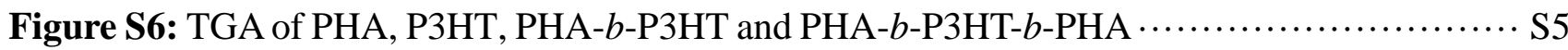

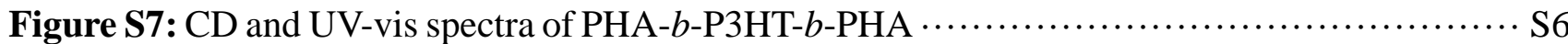

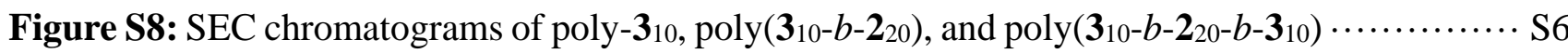

Figure S9-S11: ${ }^{1} \mathrm{H}$ NMR of poly-310, poly(310-b-220), and poly(310-b-220-b-310) $\cdots \cdots \cdots \cdots \cdots \cdots \cdot \ldots \cdot$ S7-S8

Figure S12: FT-IR spectra of poly-310, poly $\left(3_{10}-b-2_{20}\right)$, and poly $\left(3_{10}-b-2_{20}-b-3_{10}\right) \cdots \cdots \cdots \cdots \cdots \cdots \cdots \cdot$ S8

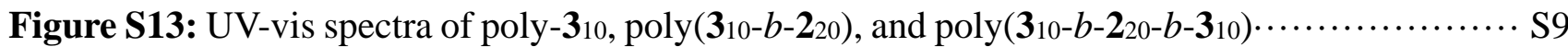

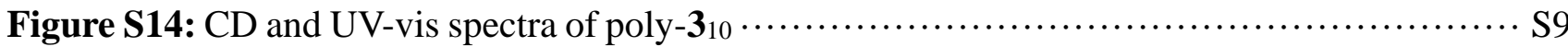

Figure S15: SEC chromatograms of poly-4m, poly $\left(4_{m}-b-2_{n}\right)$, and poly $\left(4_{m}-b-2_{n}-b-4_{0}\right) \cdots \cdots \cdots \cdots \cdots \cdot \operatorname{S} 10$

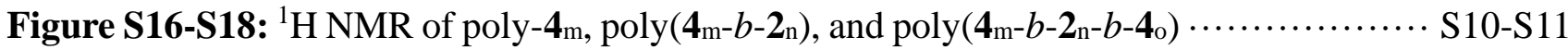

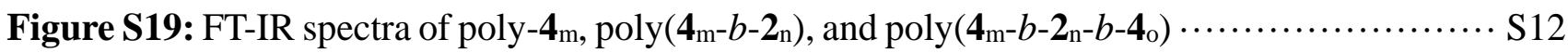

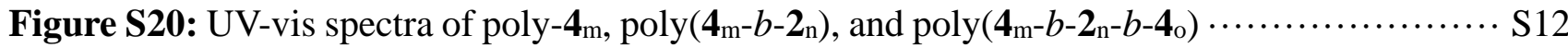

Figure S21: The photograph of poly $\left(\mathbf{4}_{15}-b-\mathbf{2}_{20}-b-\mathbf{4}_{20}\right)$ in THF and methanol $\cdots \cdots \cdots \cdots \cdots \cdots \cdots \cdots \cdot$ S12

Figure S22: Emission changes of poly $\left(\mathbf{4}_{15}-b-\mathbf{2}_{20}-b-\mathbf{4}_{20}\right)$ with the addition of TFA $\cdots \cdots \cdots \cdots \cdots \cdots \cdots \cdot$ S13

Figure S23: UV-vis and emission spectra of poly $\left(\mathbf{4}_{15}-b-\mathbf{2}_{20}-b-\mathbf{4}_{20}\right)$ in THF and water $\cdots \cdots \cdots \cdots \cdots \cdot \ldots \cdot$ S13

Figure S24: Temperature-dependent DLS curves of poly $\left(\mathbf{4}_{15}-b-\mathbf{2}_{20}-b-\mathbf{4}_{20}\right)$ in water $\cdots \cdots \cdots \cdots \cdots \cdots \cdot$ S14

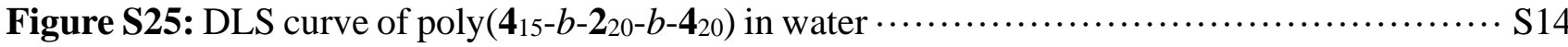

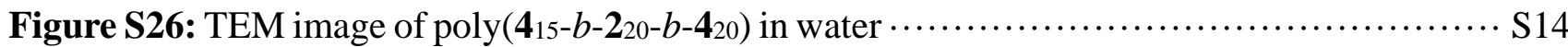

Figure S27: Cell viability assay of HepG2 cells treated with poly $\left(\mathbf{4}_{15}-b-\mathbf{2}_{20}-b-\mathbf{4}_{20}\right) \cdots \cdots \cdots \cdots \cdots \cdots \cdot$ S15

Figure S28-30: ${ }^{1} \mathrm{H}$ NMR, ${ }^{13} \mathrm{C}$ NMR, and FT-IR of monomer 3 


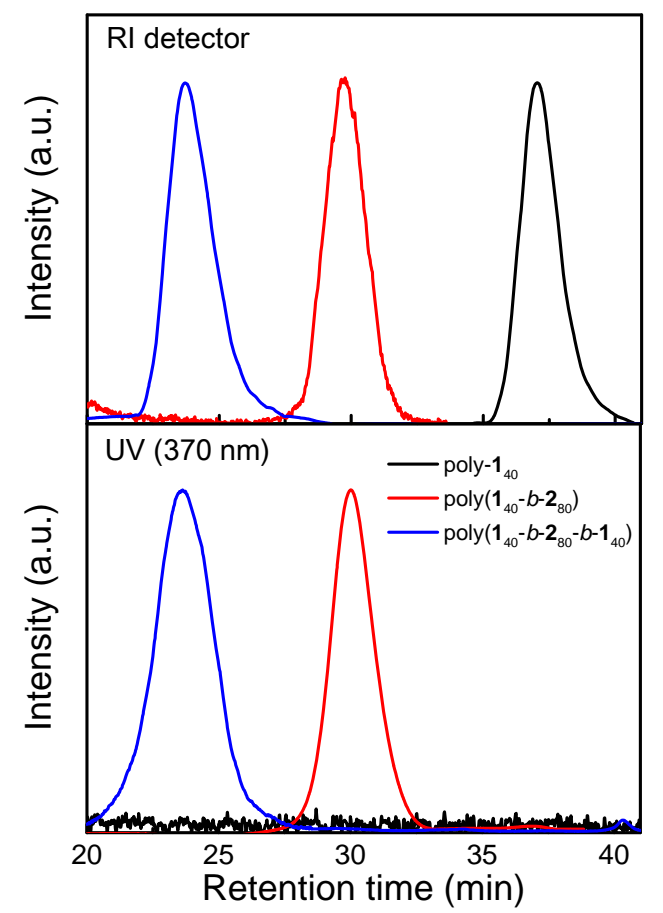

Figure S1. Size exclusion chromatograms of poly-140 homoolymer, poly $\left(\mathbf{1}_{40}-b-\mathbf{2}_{80}\right)$ diblock copolymer, and poly(140-b-280-b-140) triblock copolymer using RI and UV (at $370 \mathrm{~nm}$ ) detectors.

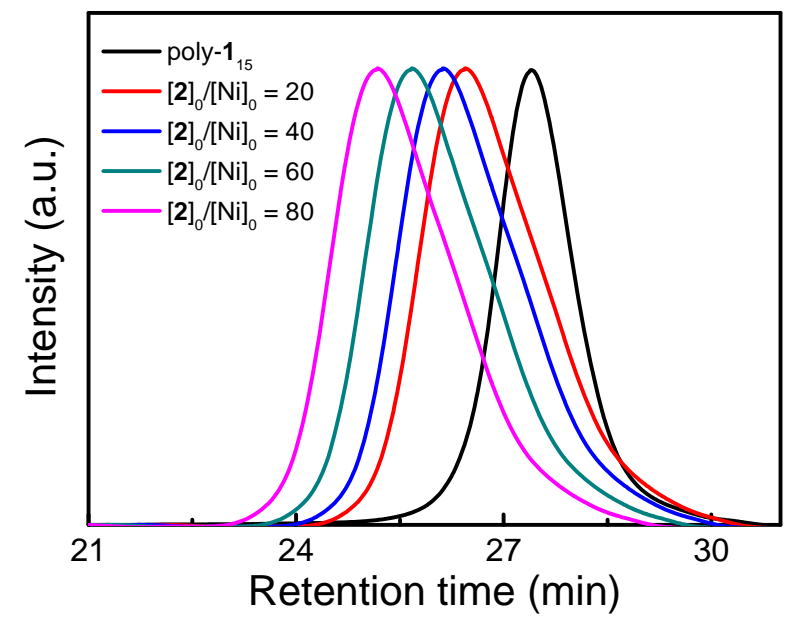

Figure S2. Size exclusion chromatograms of poly $\left(\mathbf{1}_{15}-b-\mathbf{2}_{\mathrm{n}}\right) \mathrm{s}$ prepared from the one-pot block copolymerization of 2 using Ni-terminated poly-1 $15\left(M_{\mathrm{n}}=4.2 \mathrm{kDa}, M_{\mathrm{w}} / M_{\mathrm{n}}=1.15\right)$ as a common macroinitiator in THF at room temperature with initial feed ratio of monomer to the macroinitiator is 20, 40, 60 and 80. 

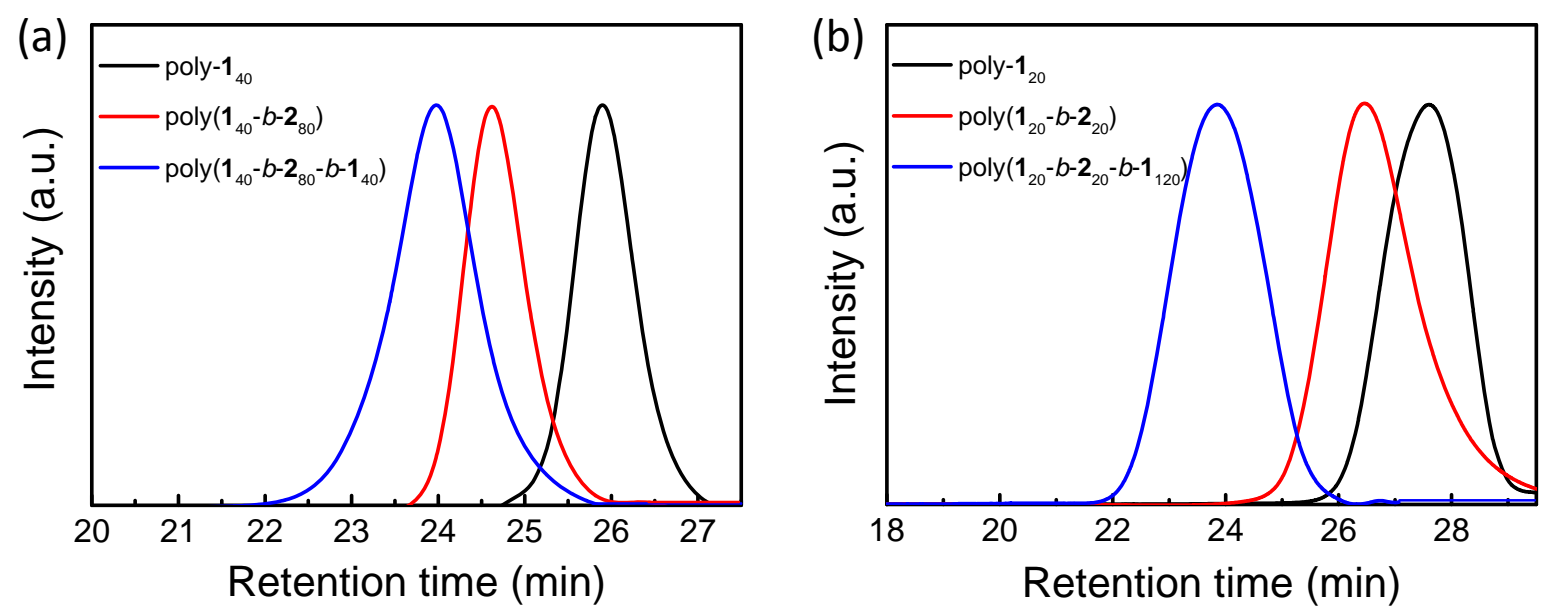

Figure S3. Size exclusion chromatograms of poly-1 $\mathbf{1}_{\mathrm{m}}$, poly $\left(\mathbf{1}_{\mathrm{m}}-b-\mathbf{2}_{\mathrm{n}}\right)$, and poly $\left(\mathbf{1}_{\mathrm{m}}-b-\mathbf{2}_{\mathrm{n}}-b-\mathbf{1}_{\mathrm{o}}\right)$. (a) run 2, and (b) run 3 in Table 1 in main text.

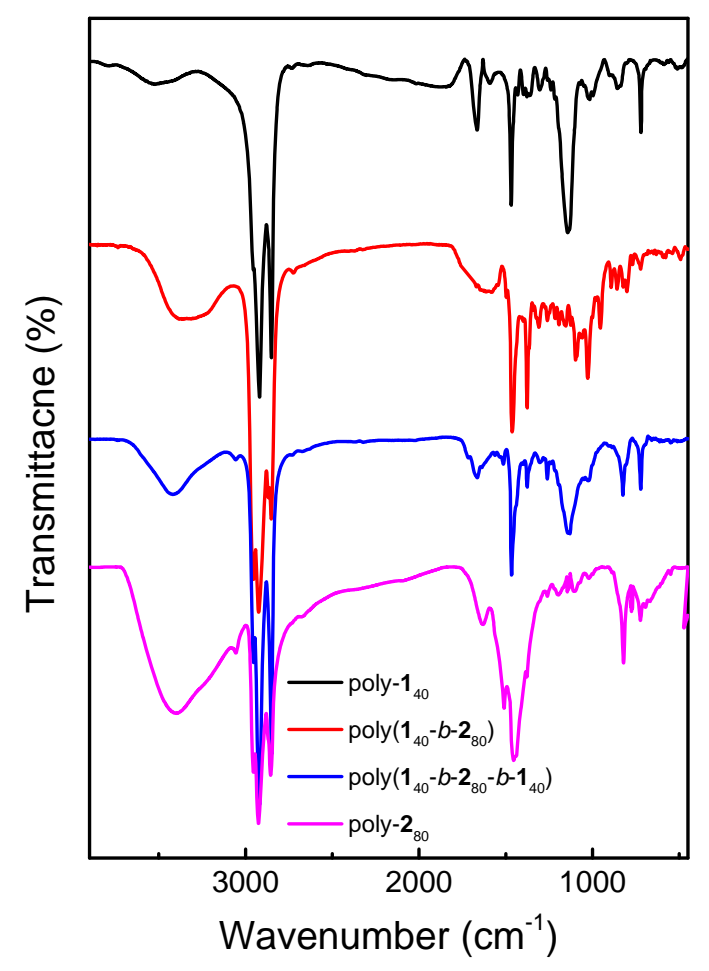

Figure S4. FT-IR spectra of poly-140, poly-280, poly $\left(\mathbf{1}_{40}-b-\mathbf{2}_{80}\right)$, and poly $\left(\mathbf{1}_{40}-b-\mathbf{2}_{80}-b-\mathbf{1}_{40}\right)$ measured at $25{ }^{\circ} \mathrm{C}$ using $\mathrm{KBr}$ pellets. 


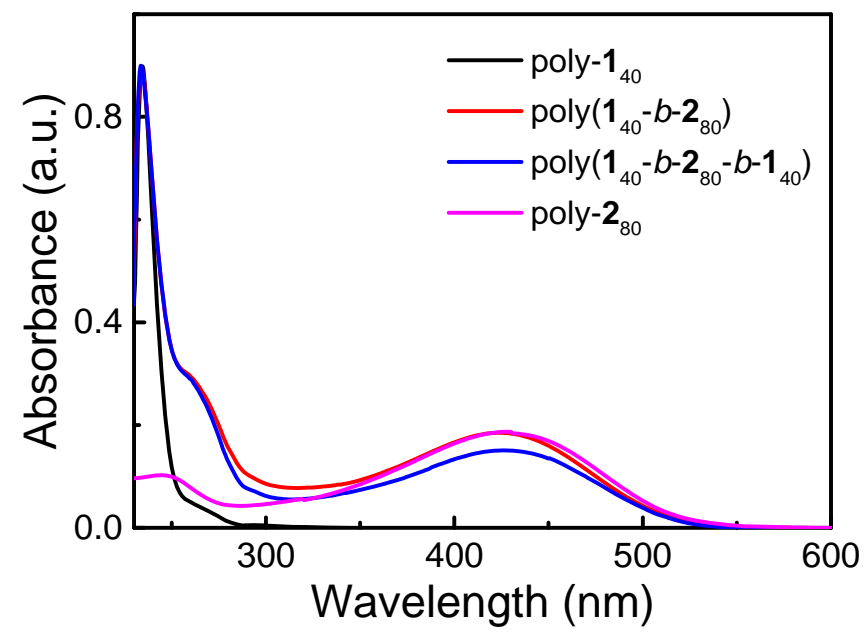

Figure S5. Normalized UV-vis absorption spectra of poly-140, poly-280, poly(140- $\left.b-\mathbf{2}_{80}\right)$, and poly(140$\left.b-\mathbf{2}_{80}-b-\mathbf{1}_{40}\right)$ in THF at $25^{\circ} \mathrm{C}(c=0.2 \mathrm{~g} / \mathrm{L})$.

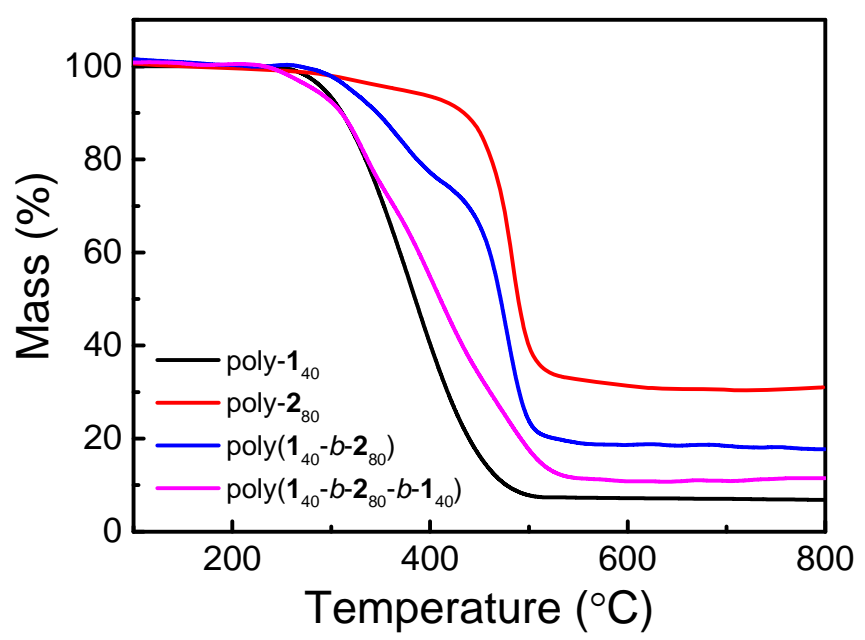

Figure S6. TGA curves for poly-140, poly-2 80 , poly $\left(\mathbf{1}_{40}-b-\mathbf{2}_{80}\right)$, and poly $\left(\mathbf{1}_{40}-b-\mathbf{2}_{80}-b-\mathbf{1}_{40}\right)$ (conditions: $\mathrm{N}_{2}$ atmosphere; scan rate $\left.=10^{\circ} \mathrm{C} / \mathrm{min}\right)$. 


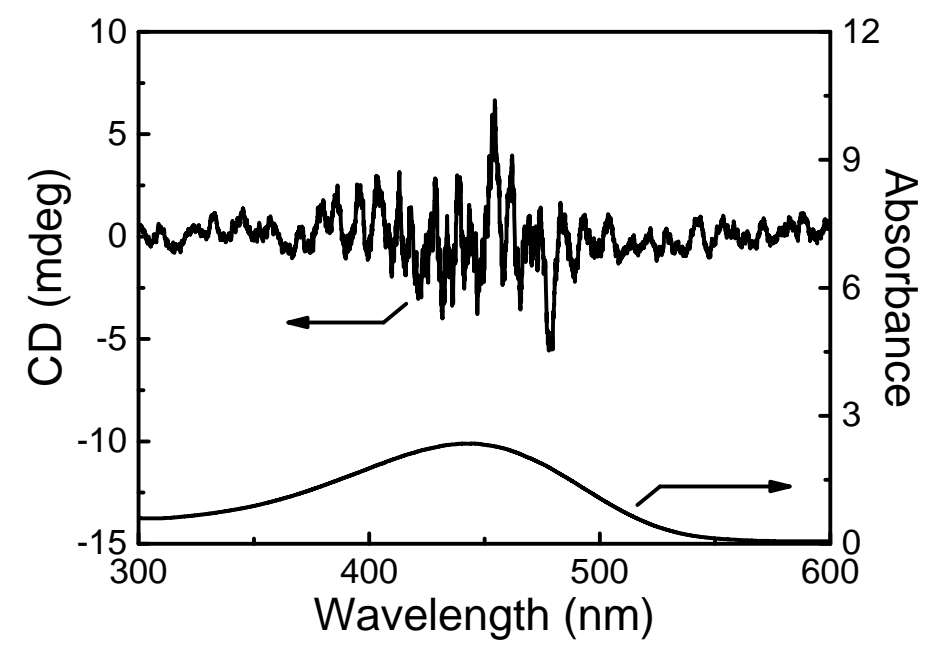

Figure S7. CD and UV-vis absorption spectra of poly(140-b-280-b-140) block copolymers in THF at 25 ${ }^{\circ} \mathrm{C}(c=2.0 \mathrm{~g} / \mathrm{L})$.

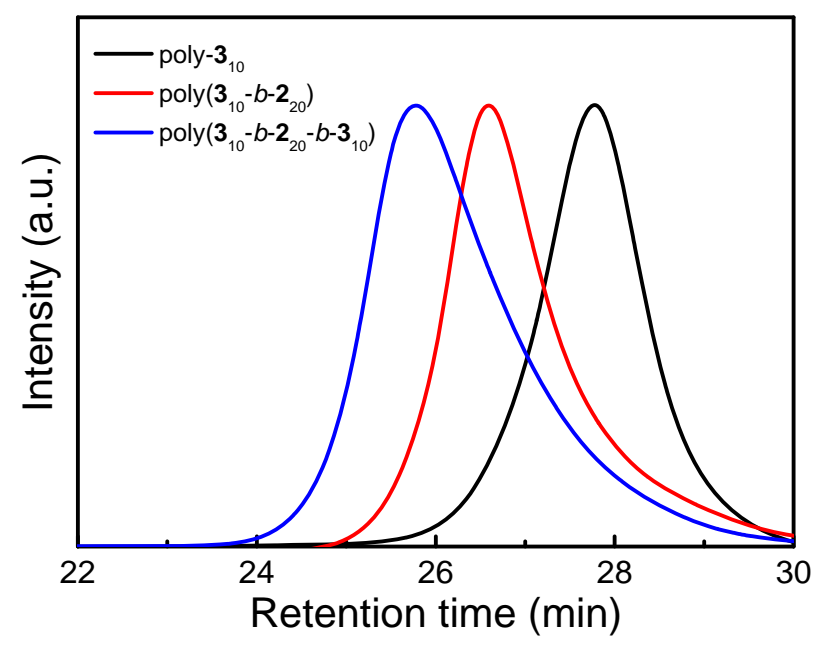

Figure S8. Size exclusion chromatograms of poly-310, poly(310-b-220), and poly(3 $\left.\mathbf{3}_{10}-b-\mathbf{2}_{20}-b-\mathbf{3}_{10}\right)$ block copolymers. SEC conditions: eluent $=\mathrm{THF}$, temperature $=40^{\circ} \mathrm{C}$. 


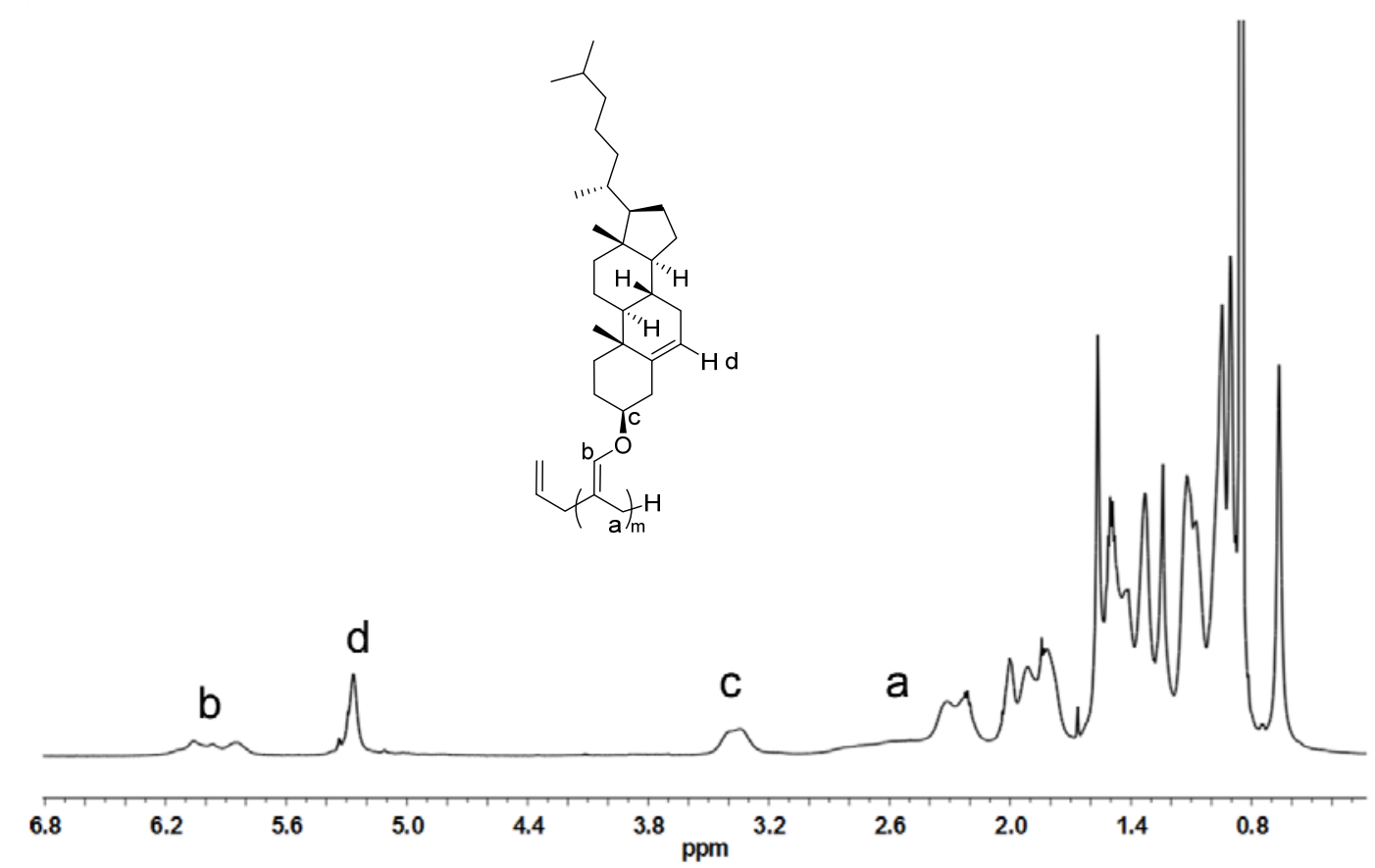

Figure S9. ${ }^{1} \mathrm{H}$ NMR $(600 \mathrm{MHz})$ spectrum of poly-3 $3_{10}$ measured in $\mathrm{CDCl}_{3}$ at $25{ }^{\circ} \mathrm{C}$.
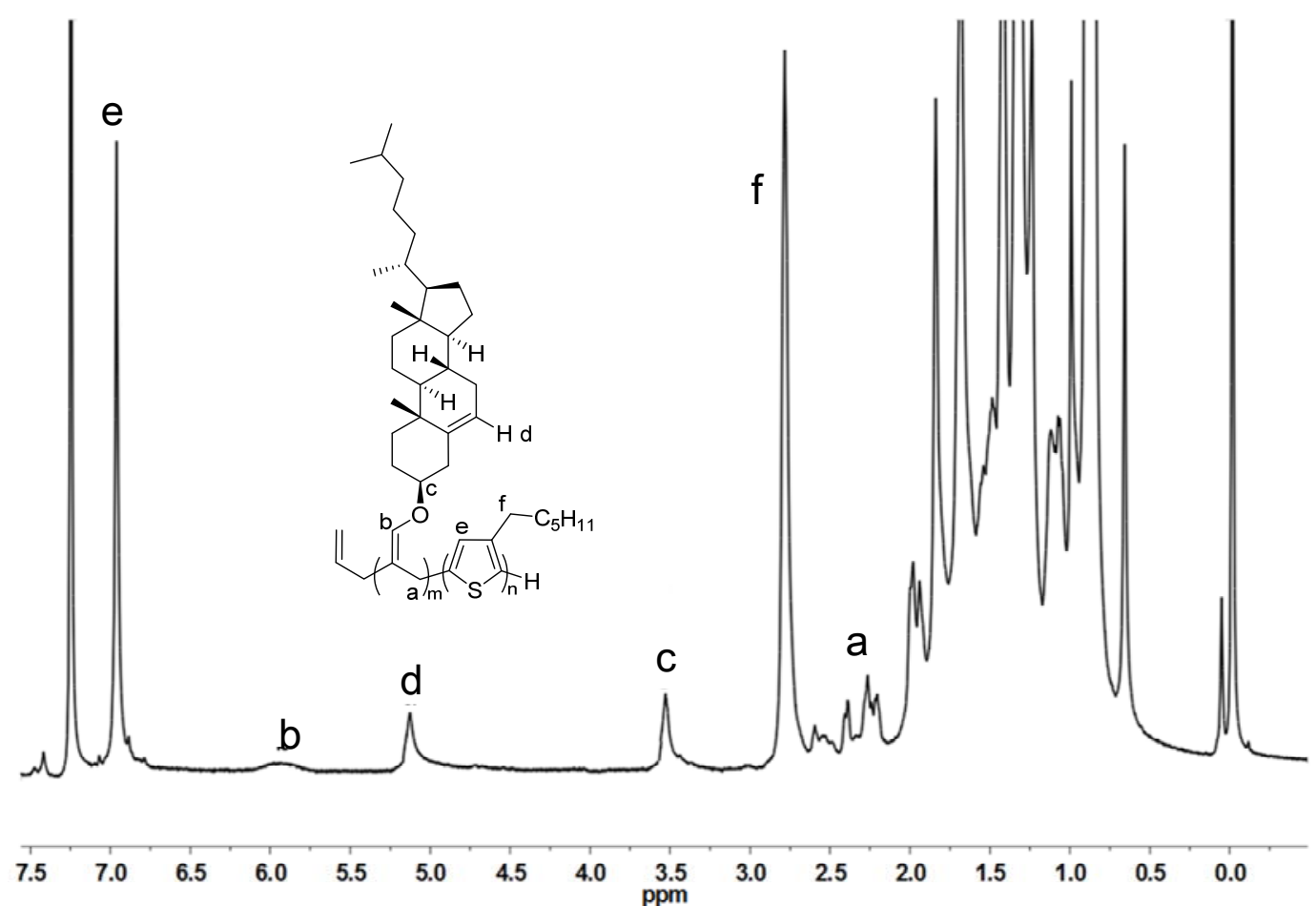

Figure S10. ${ }^{1} \mathrm{H}$ NMR $(600 \mathrm{MHz})$ spectrum of poly(310-b-220) measured in $\mathrm{CDCl}_{3}$ at $25{ }^{\circ} \mathrm{C}$. 


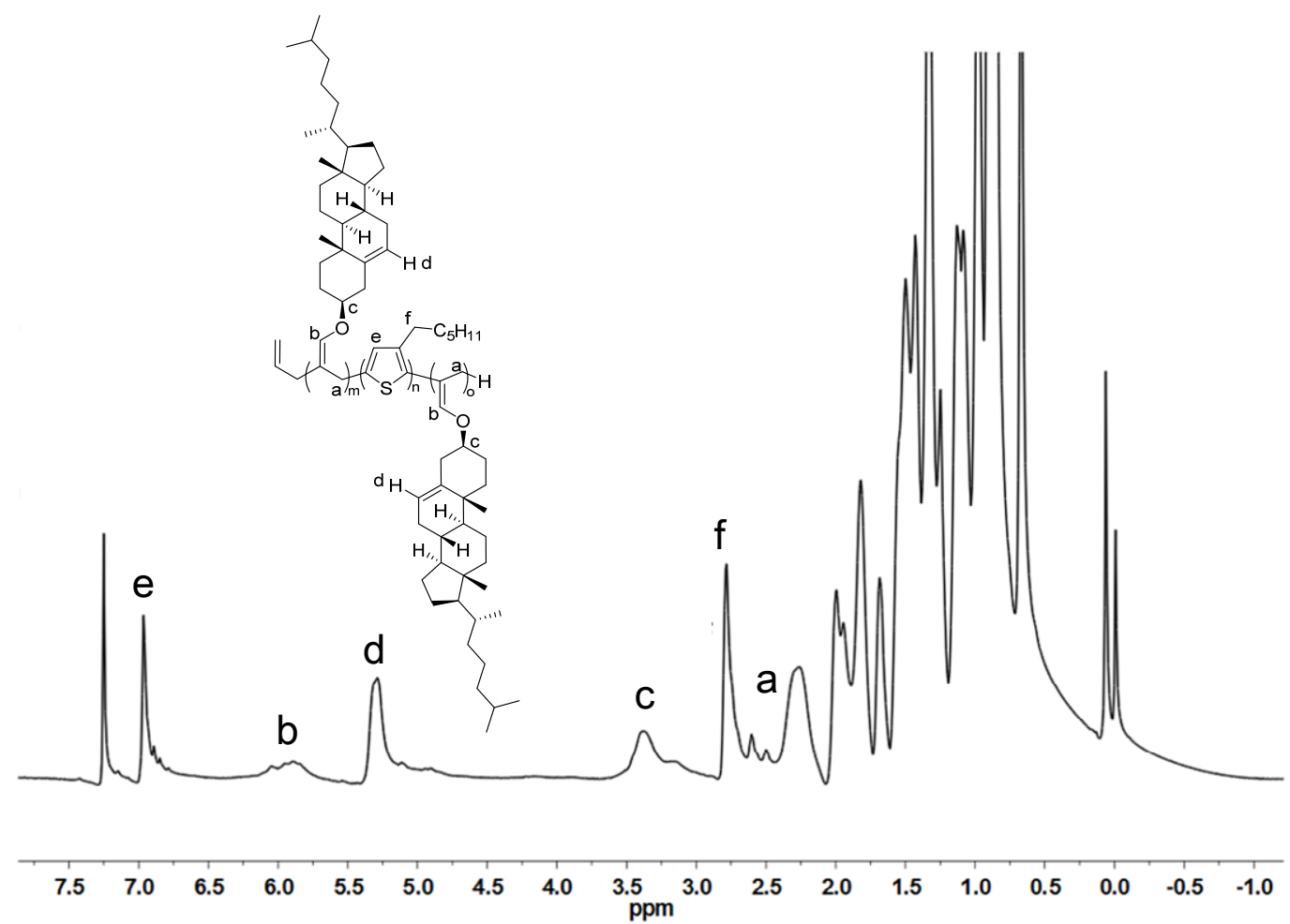

Figure S11. ${ }^{1} \mathrm{H}$ NMR $(600 \mathrm{MHz})$ spectrum of poly $\left(3_{10}-b-2_{20}-b-3_{10}\right)$ measured in $\mathrm{CDCl}_{3}$ at $25{ }^{\circ} \mathrm{C}$.

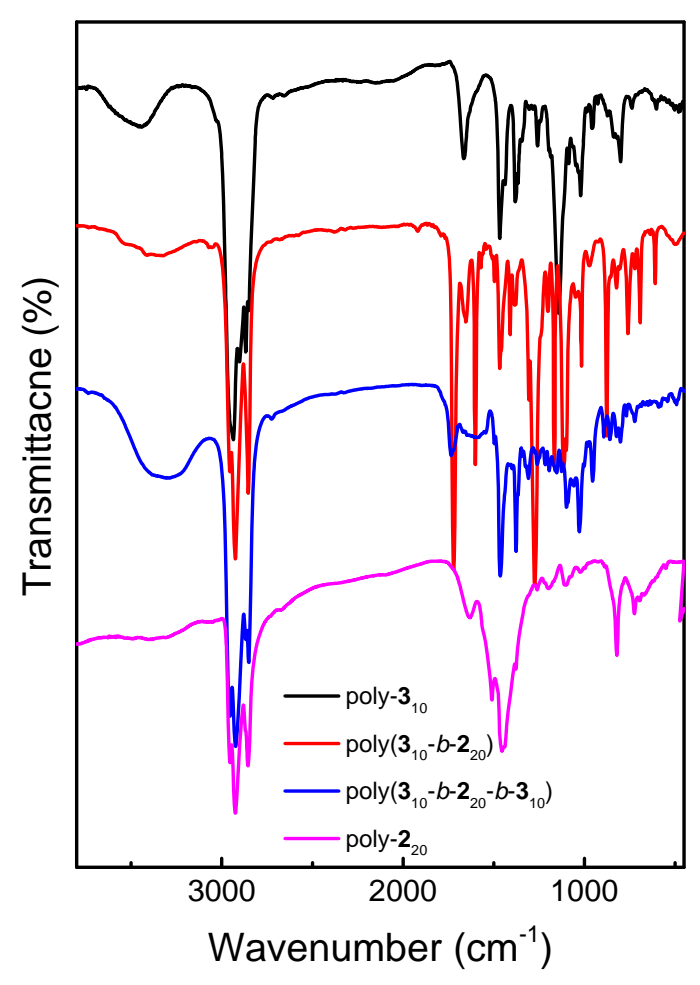

Figure S12. FT-IR spectra of poly-310, poly-220, poly(3 $\left.\mathbf{3}_{10}-b-\mathbf{2}_{20}\right)$, and poly(310-b-220-b-310) measured at $25^{\circ} \mathrm{C}$ using $\mathrm{KBr}$ pellets. 


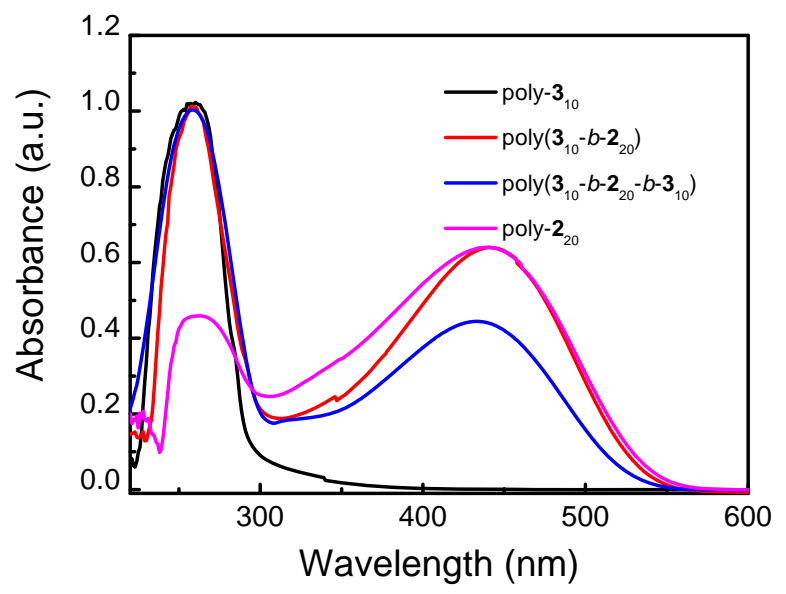

Figure S13. Normalized UV-vis absorption spectra of poly-3 $\mathbf{3}_{10}$, poly-220, poly(310-b-220), and poly(310$\left.b-\mathbf{2}_{20}-b-\mathbf{3}_{10}\right)$ in THF at $25^{\circ} \mathrm{C}(c=0.2 \mathrm{~g} / \mathrm{L})$.

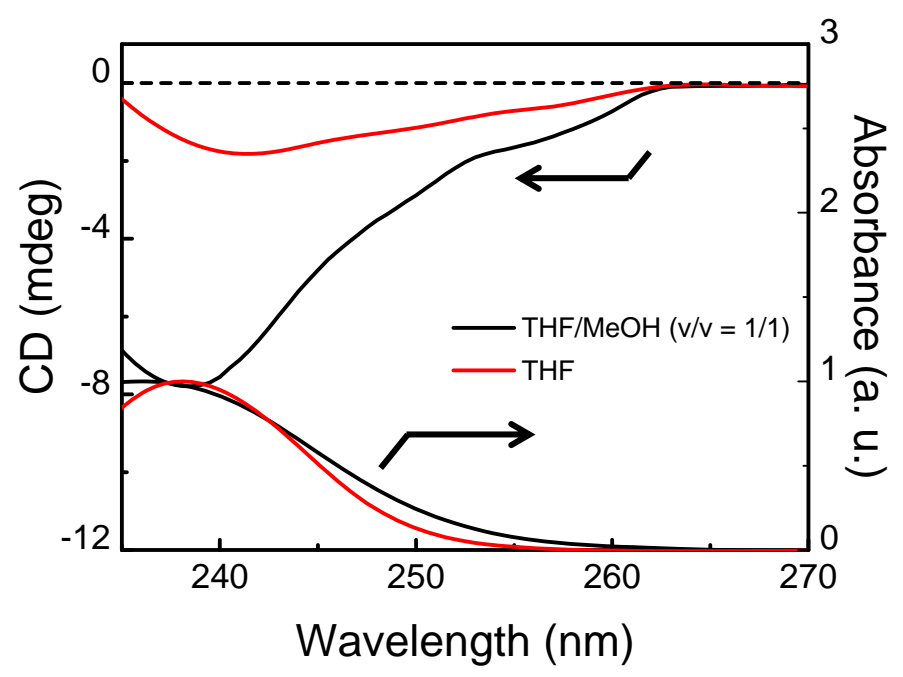

Figure S14. The CD and UV-vis absorption spectra of poly-310 block copolymers in THF and $\mathrm{THF} / \mathrm{methanol}(\mathrm{v} / \mathrm{v}=1 / 1)$ at $25^{\circ} \mathrm{C}(c=2 \mathrm{~g} / \mathrm{L})$. 

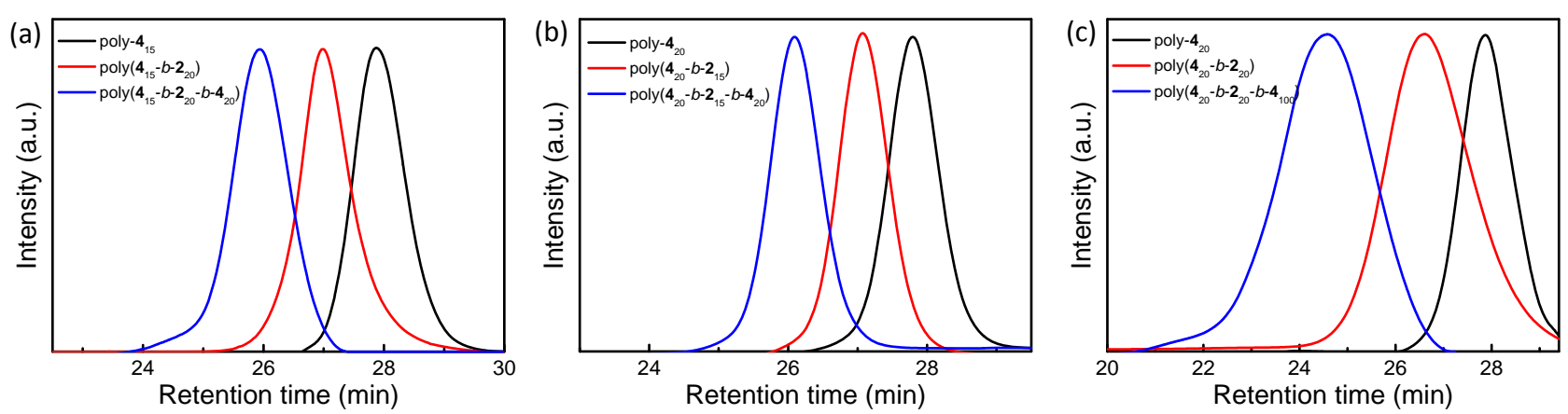

Figure S15. Size exclusion chromatograms of poly-4m, poly $\left(4_{m}-b-2 n\right)$ and poly $\left(4_{m}-b-2 n-b-4_{o}\right)$. (a) run 5, (b) run 6, and (c) run 7 in Table 1 in main text.

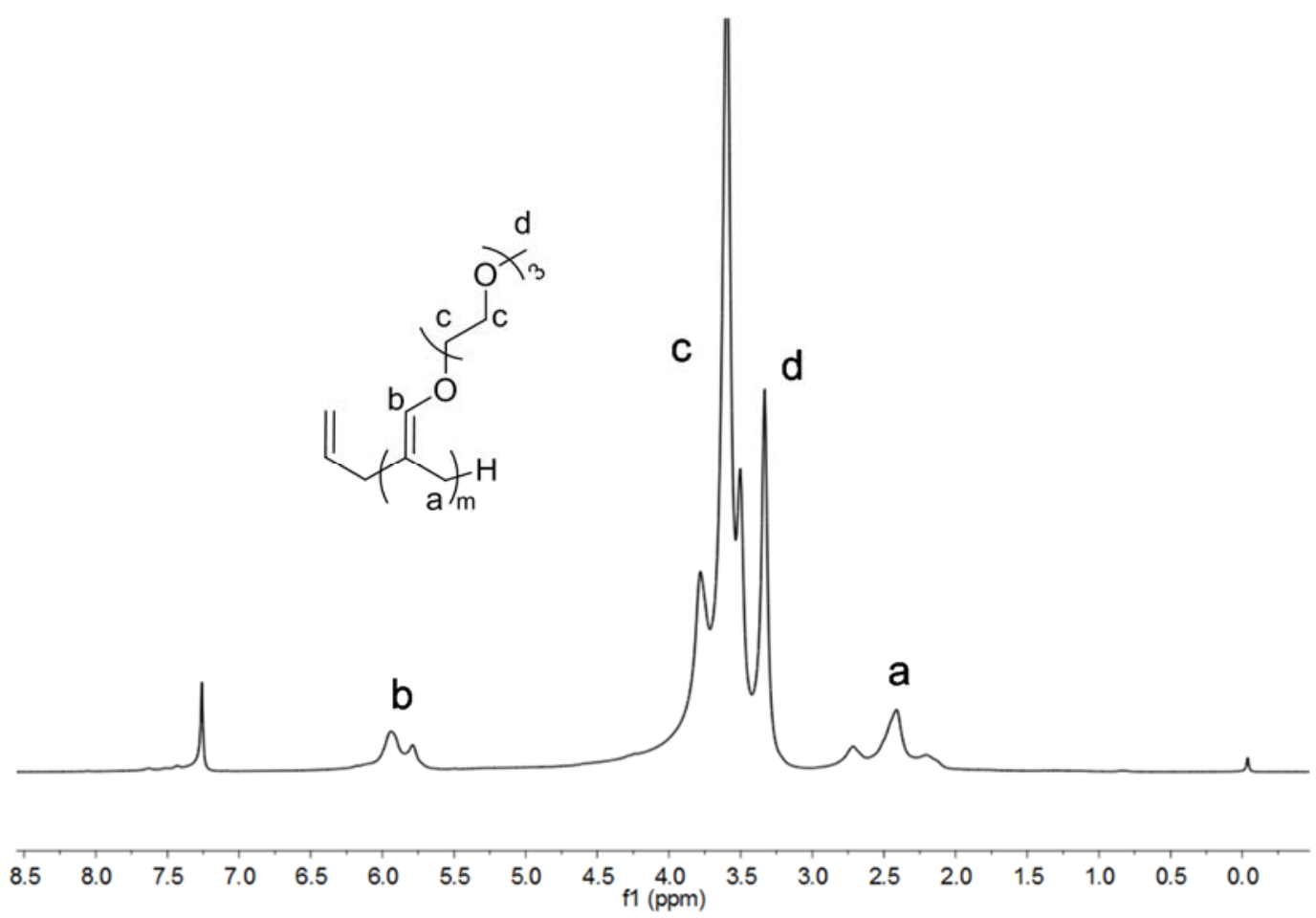

Figure S16. ${ }^{1} \mathrm{H}$ NMR (600 MHz) spectrum of poly-420 measured in $\mathrm{CDCl}_{3}$ at $25{ }^{\circ} \mathrm{C}$. 


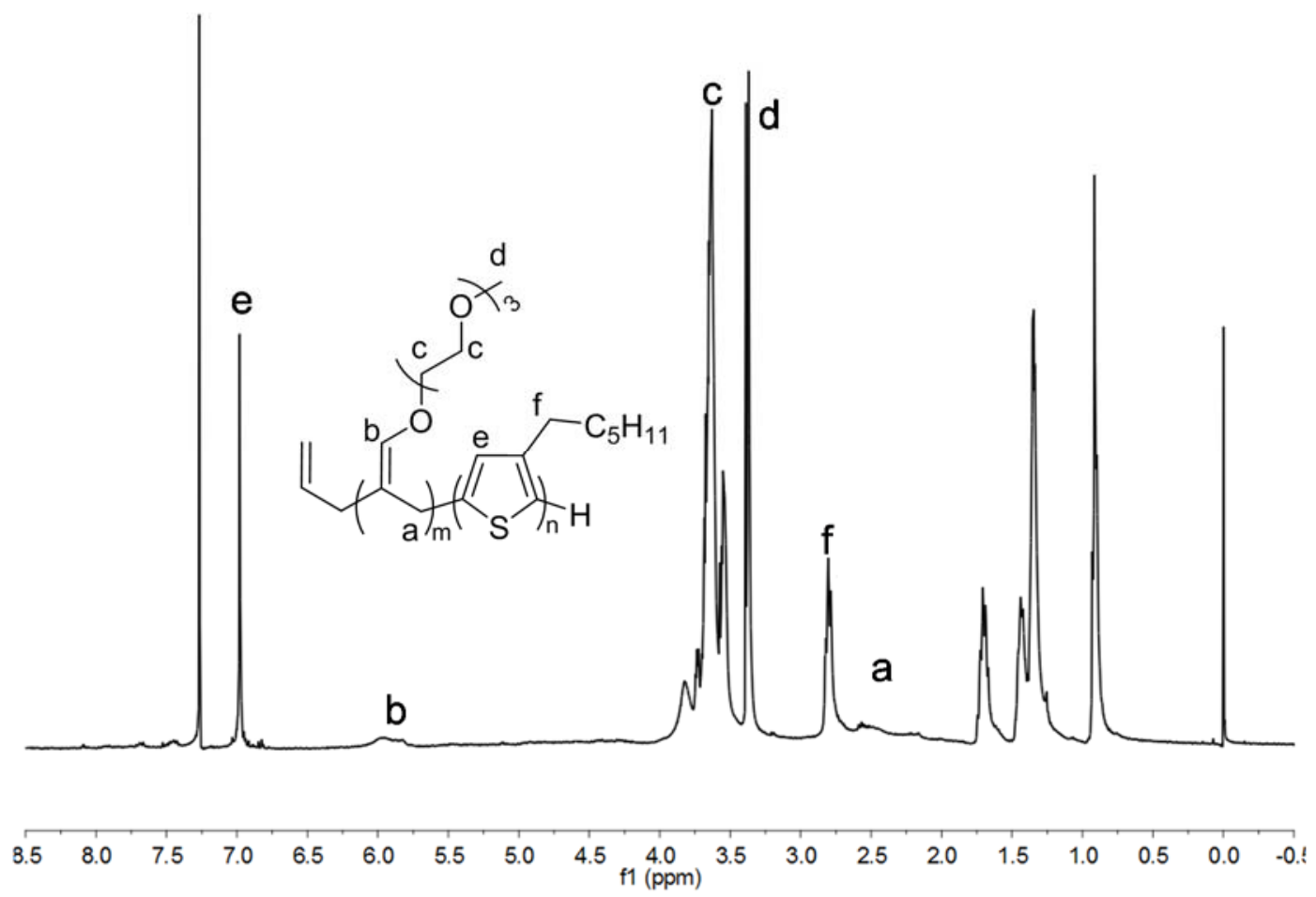

Figure S17. ${ }^{1} \mathrm{H}$ NMR $(600 \mathrm{MHz})$ spectrum of poly $\left(\mathbf{4}_{20}-b-\mathbf{2}_{20}\right)$ measured in $\mathrm{CDCl}_{3}$ at $25{ }^{\circ} \mathrm{C}$.

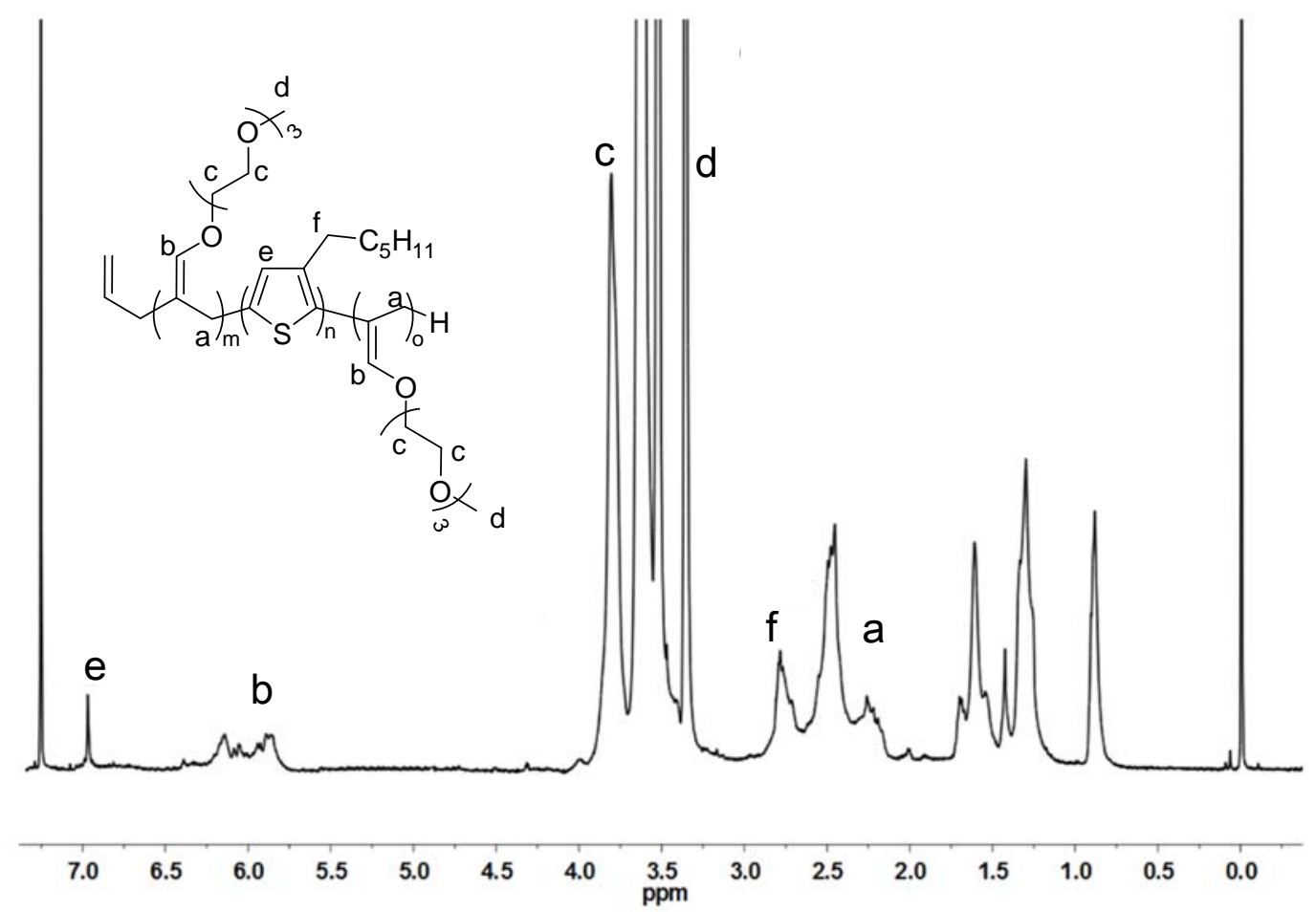

Figure S18. ${ }^{1} \mathrm{H}$ NMR $(600 \mathrm{MHz})$ spectrum of poly(420-b-220-b-4100) measured in $\mathrm{CDCl}_{3}$ at $25{ }^{\circ} \mathrm{C}$. 


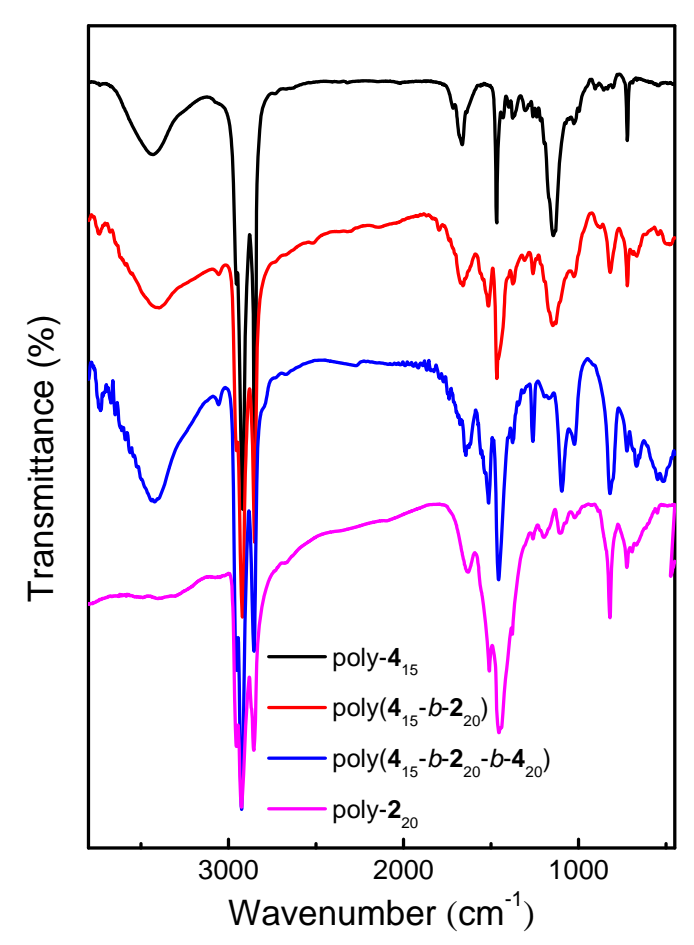

Figure S19. FT-IR spectra of poly-4${ }_{15}$, poly-220, poly(4 $\left.\mathbf{4}_{15}-b-\mathbf{2}_{20}\right)$, and poly $\left(\mathbf{4}_{15}-b-\mathbf{2}_{20}-b-\mathbf{4}_{20}\right)$ measured at $25{ }^{\circ} \mathrm{C}$ using $\mathrm{KBr}$ pellets.

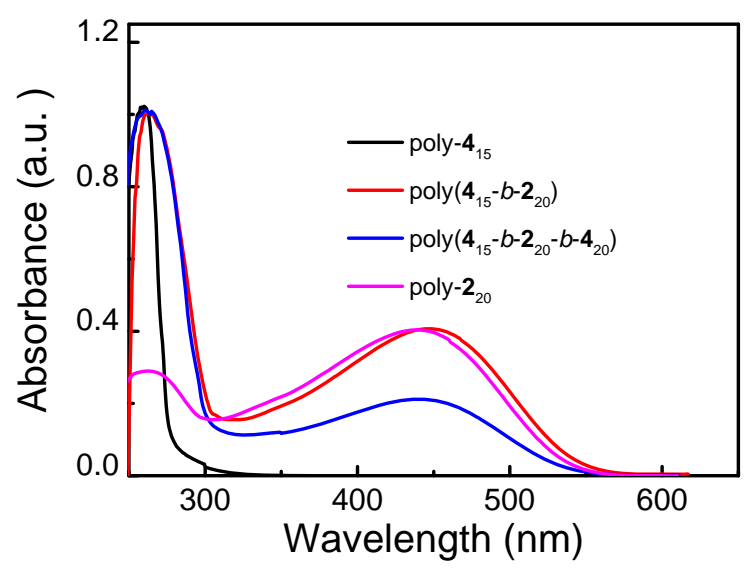

Figure S20. Normalized UV-vis absorption spectra of poly-415, poly-220, poly(415-b-220), and poly(415$\left.b-\mathbf{2}_{20}-b-\mathbf{4}_{20}\right)$ in THF at $25^{\circ} \mathrm{C}(c=0.2 \mathrm{~g} / \mathrm{L})$.

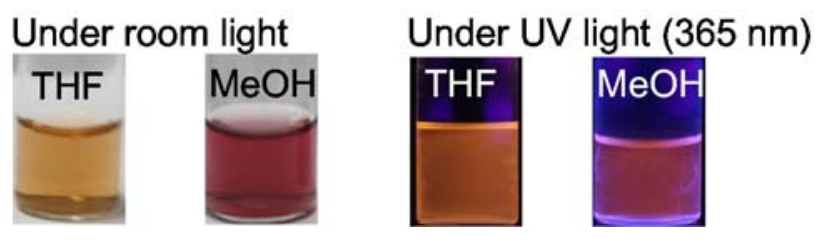

Figure S21. The photographs of poly $\left(\mathbf{4}_{15}-b-\mathbf{2}_{20}-b-\mathbf{4}_{20}\right)$ in THF and methanol under room light and UV light at $365 \mathrm{~nm}$ at $25^{\circ} \mathrm{C}(c=0.2 \mathrm{~g} / \mathrm{L})$. 


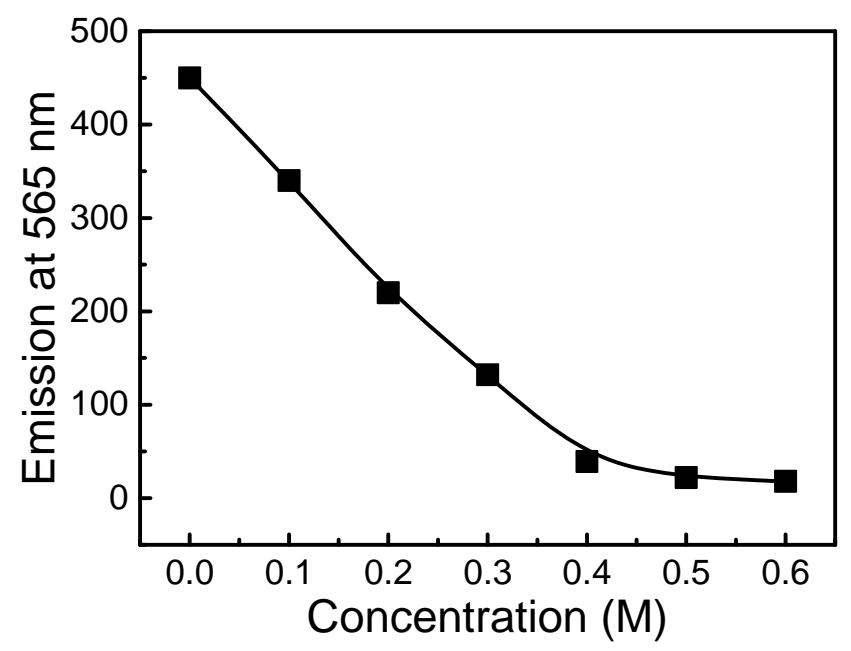

Figure S22. Emission changes of poly $\left(\mathbf{4}_{15}-b-\mathbf{2}_{20}-b-\mathbf{4}_{20}\right)(c=0.2 \mathrm{~g} / \mathrm{L})$ at $565 \mathrm{~nm}$ in $\mathrm{CH}_{2} \mathrm{Cl}_{2}$ with the concentration of the added TFA at $25^{\circ} \mathrm{C}$.

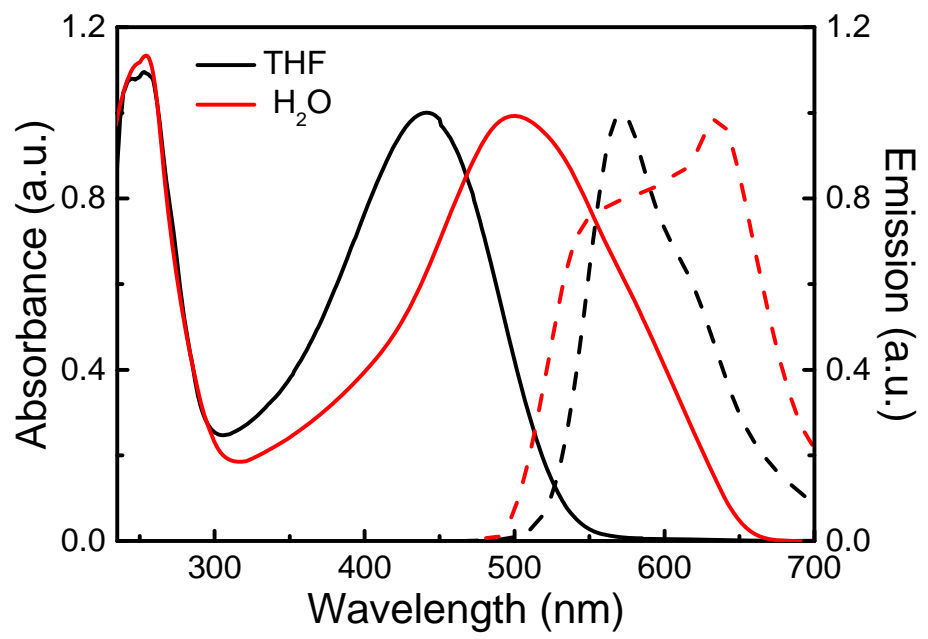

Figure S23. The UV-vis (solid lines) and emission (dash lines) spectra of poly(4 $\left.\mathbf{4}_{15}-b-\mathbf{2}_{20}-b-\mathbf{4}_{20}\right)$ in THF and water. 


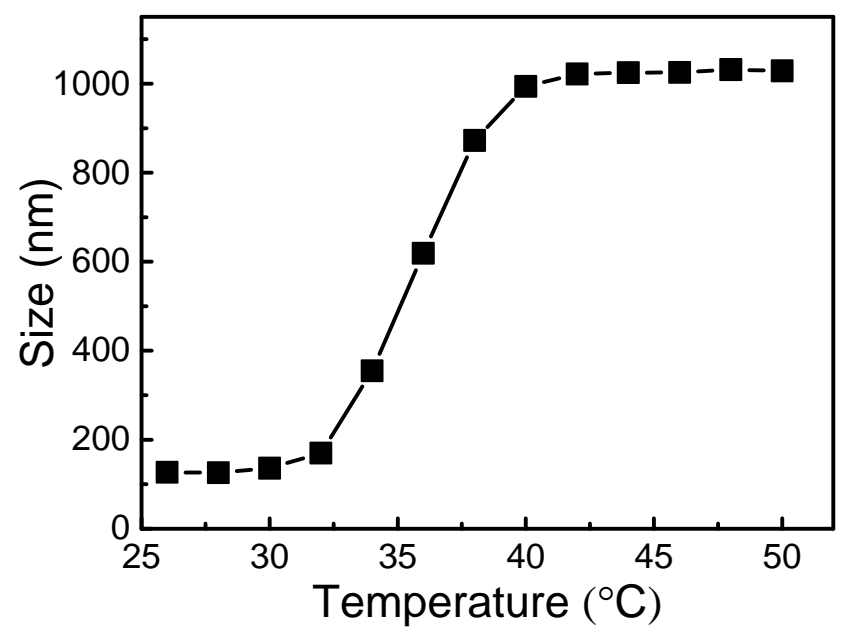

Figure S24. DLS curves of poly $\left(\mathbf{4}_{15}-b-\mathbf{2}_{20}-b-\mathbf{4}_{20}\right)$ in water at different temperature $(c=2.0 \mathrm{~g} / \mathrm{L})$.

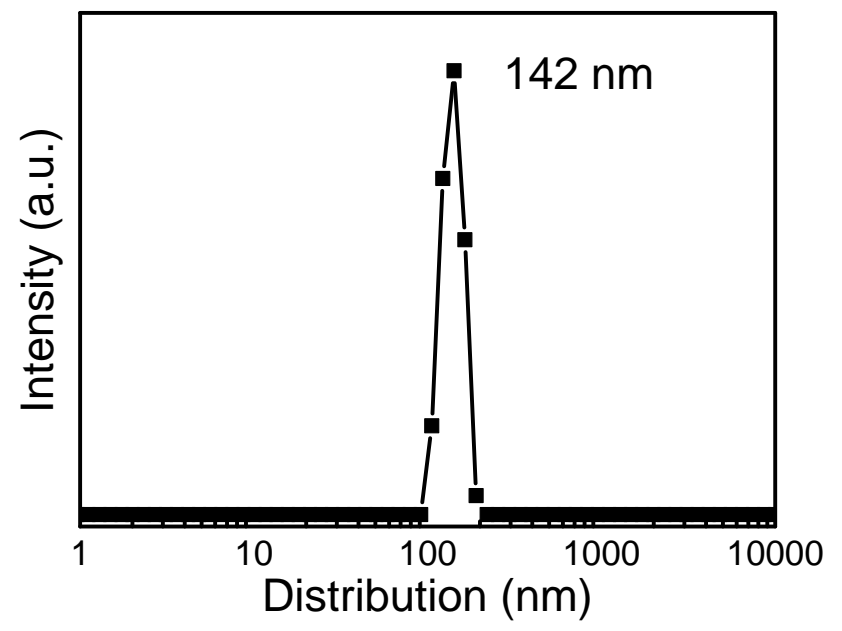

Figure S25. DLS curve of poly $\left(\mathbf{4}_{15}-b-\mathbf{2}_{20}-b-\mathbf{4}_{20}\right)$ in water at $25{ }^{\circ} \mathrm{C}(c=0.1 \mathrm{~g} / \mathrm{L})$.

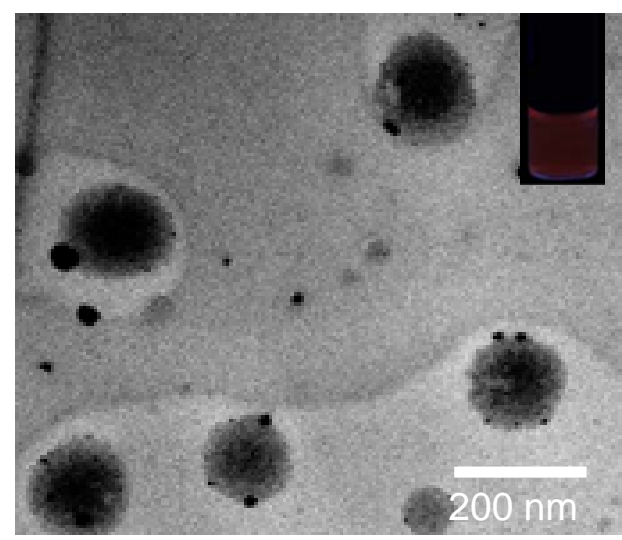

Figure S26. The TEM image of poly $\left(\mathbf{4}_{15}-b-\mathbf{2}_{20}-b-\mathbf{4}_{20}\right)$ casted from water (inset: the photographic of poly $\left(\mathbf{4}_{15}-b-\mathbf{2}_{20}-b-\mathbf{4}_{20}\right)$ in water under the illumination of UV light). 


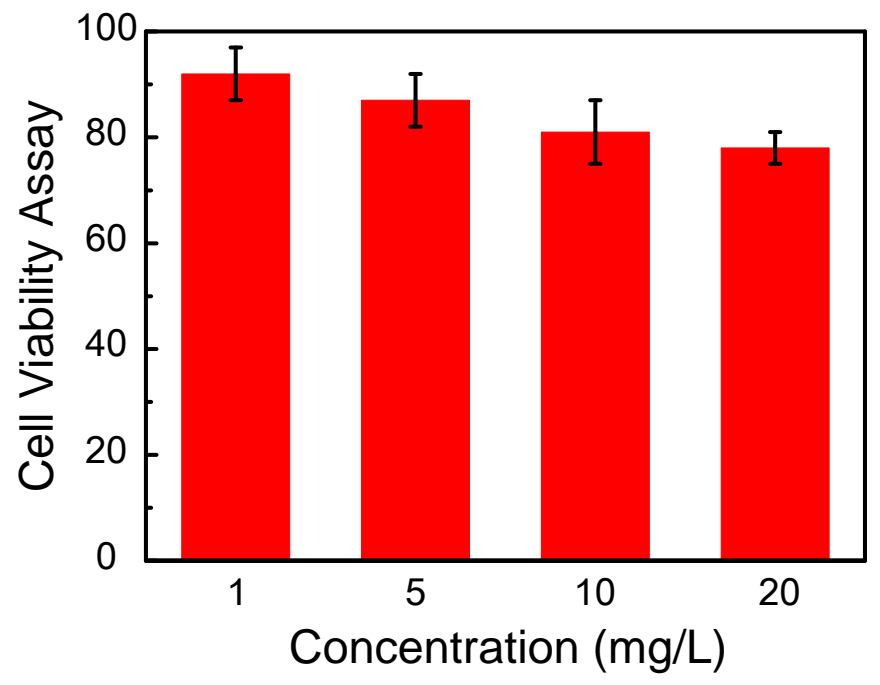

Figure S27. The cell viability assay of HepG2 cells treated with poly $\left(\mathbf{4}_{15}-b-\mathbf{2}_{20}-b-\mathbf{4}_{20}\right)$ at different concentrations for $24 \mathrm{~h}$.

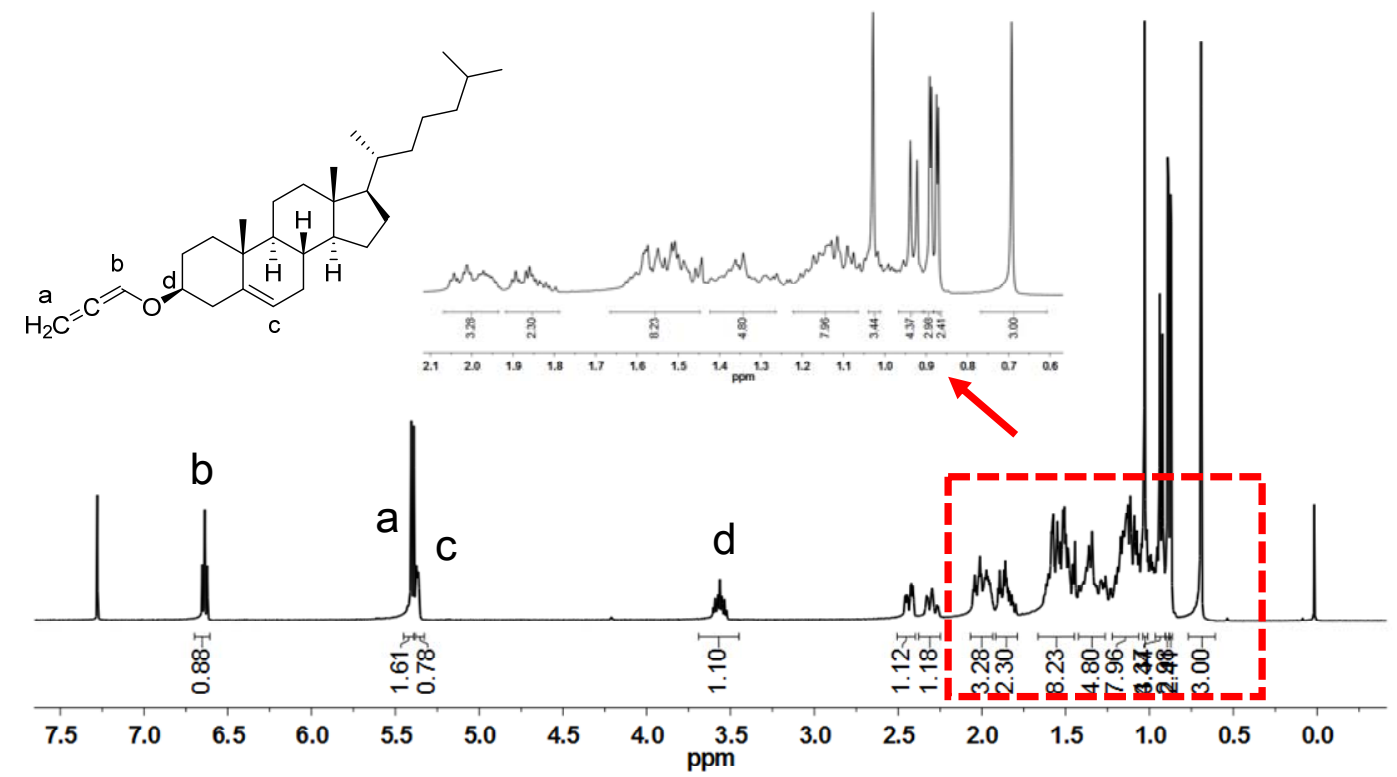

Figure S28. ${ }^{1} \mathrm{H}$ NMR (400 MHz) spectrum of monomer 3 measured in $\mathrm{CDCl}_{3}$ at $25{ }^{\circ} \mathrm{C}$. 

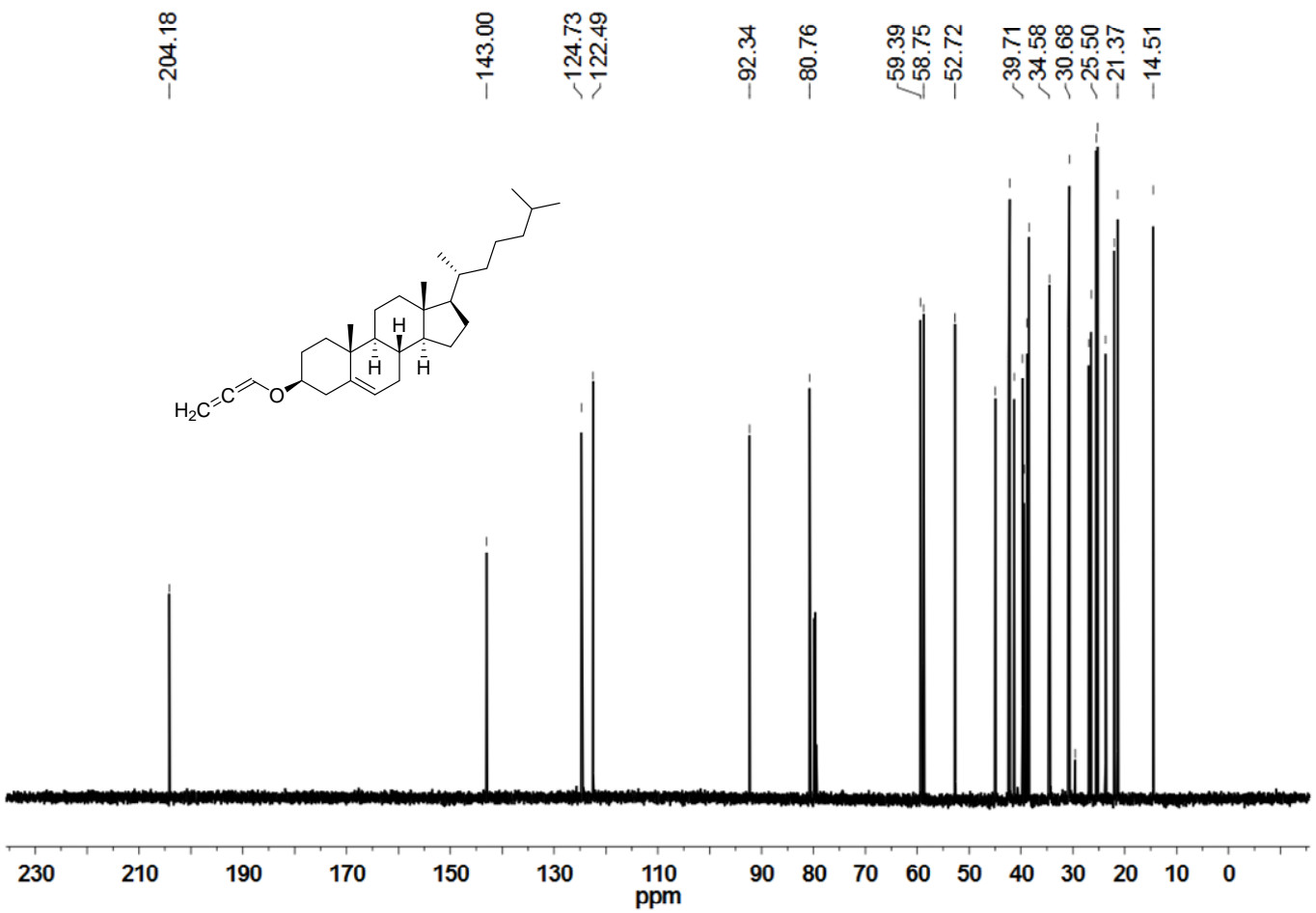

Figure S29. ${ }^{13} \mathrm{C}$ NMR (150 MHz) spectrum of monomer 3 measured in $\mathrm{CDCl}_{3}$ at $25{ }^{\circ} \mathrm{C}$.

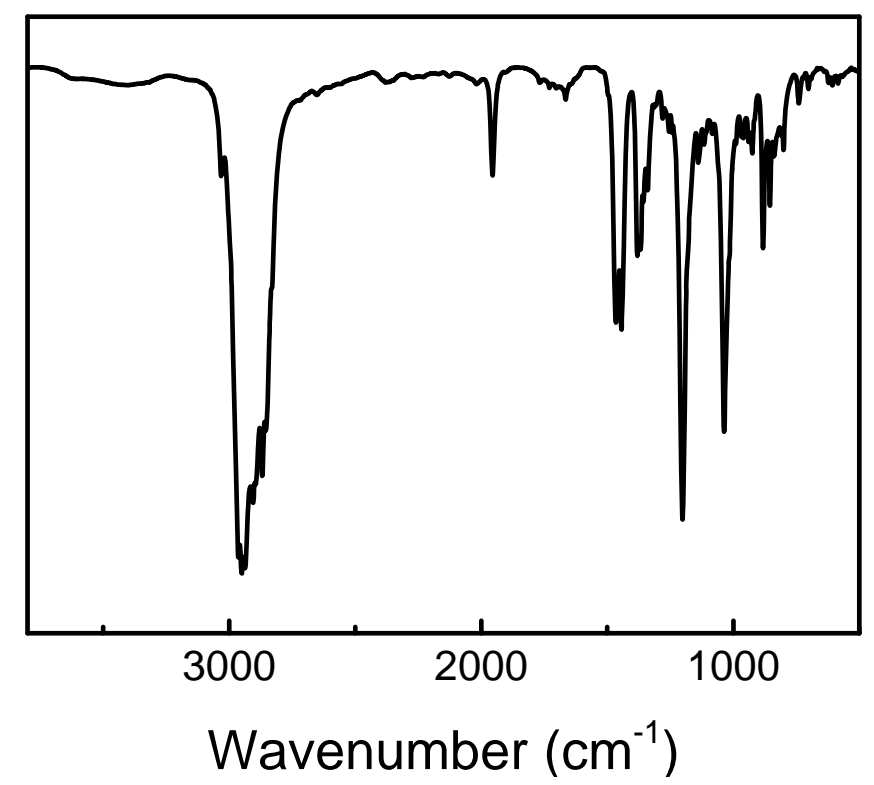

Figure S30. The FT-IR spectrum of monomer 3 measured at $25^{\circ} \mathrm{C}$ using $\mathrm{KBr}$ pellets. 